\title{
Gelatinous zooplankton assemblages associated with water masses in the Humboldt Current System, and potential predatory impact by Bassia bassensis (Siphonophora: Calycophorae)
}

\author{
F. Pagès ${ }^{1, *}$, H. E. González ${ }^{2}$, M. Ramón ${ }^{1}$, M. Sobarzo ${ }^{3}$, J.-M. Gili ${ }^{1}$ \\ ${ }^{1}$ Institut de Ciències del Mar (CSIC), Plaça del Mar s/n, 08039 Barcelona, Catalunya, Spain \\ ${ }^{2}$ Instituto de Biología Marina, Universidad Austral de Chile, Casilla 567, Valdivia, Chile \\ ${ }^{3}$ Centro EULA-Chile, Universidad de Concepción, Casilla 160-C, Concepción, Chile
}

\begin{abstract}
Large numbers of gelatinous zooplankton were collected off Mejillones Peninsula, Chile (Humboldt Current System) in January 1997 during an oceanographic cruise. The area was characterized by the mixing of 3 water masses and the development of coastal upwelling. Siphonophores were the predominant group at most of the stations and the calycophoran Bassia bassensis was overwhelmingly the most abundant species. Five group associations were distinguishable in relation to the water masses identified. Siphonophores were associated with Subtropical Surface Water, the ctenophore Pleurobrachia sp. with Subantarctic Water, the pelagic tunicate Salpa fusiformis with Equatorial Subsurface Water, an assemblage of all gelatinous groups with mixed waters, and a low occurrence of gelatinous groups with upwelled Equatorial Subsurface Water. Molluscs were the group least associated with any water mass. The potential percentage of small copepods removed by $B$. bassensis ranged between 2.9 and $69.3 \%$. Our results indicate that $B$. bassensis was the most important secondary predator in the top $50 \mathrm{~m}$ of the water column, and could therefore have had a significant trophic impact on the population of small copepods off the Mejillones Peninsula during the sampling period, where small copepods constituted $80.6 \%$ of the total mesozooplankton community. This siphonophore potentially ingested an average of $17.3 \%$ of the total copepod biomass.
\end{abstract}

KEY WORDS: Siphonophores $\cdot$ Ctenophores $\cdot$ Salps $\cdot$ Molluscs $\cdot$ Water masses $\cdot$ Humboldt Current Bassia $\cdot$ Copepods $\cdot$ Predation

\section{INTRODUCTION}

The Humboldt Current System (HCS) extends along $4000 \mathrm{~km}$ of the most productive marine region of South America. Like most eastern boundary currents (Benguela, California, Sahara), it is characterized by the equatorward flow of cold, low-salinity water. However, it masks a complex set of other currents and countercurrents that occur semipermanently between the coast and $1000 \mathrm{~km}$ offshore. This flow heterogeneity reflects

*E-mail: fpages@icm.csic.es the seasonality and mesoscale processes that characterize the pelagic dynamics in this upwelling system (Alheit \& Bernal 1993).

Present knowledge of the HCS pelagic food webs is mainly centred on the top trophic levels because of the importance of the economic resources derived from the fisheries of Chile and Perú. In northern Chile $\left(18^{\circ} 21^{\prime}\right.$ to $\left.24^{\circ} 00^{\prime} \mathrm{S}\right)$, there is one of the most important pelagic fisheries in the world. In 1997, it reached $1743718 \mathrm{t}$ of fish landings, which contributed 29\% (mostly the anchovy Engraulis ringens Jenyns) to the total for Chile (Sernapesca 1998). However, this dropped to $223928 \mathrm{t}$ 
in 1998 (Sernapesca 1999), probably because of an El Niño. The southern third of this zone, off Mejillones Peninsula and Antofagasta ( $22^{\circ} 30^{\prime}$ to $\left.24^{\circ} 00^{\prime} \mathrm{S}\right)$ usually shows a high productivity that is associated with a southward undercurrent, the Equatorial Subsuperficial Water (ESSW), that transports waters rich in nutrients, and with a wind-driven and topographically enhanced coastal upwelling. In this important fishing area, the processes connecting primary production to the secondary consumers are only superficially known. This has recently promoted the study of the mesoscale physical variability of the area coupled with the dynamics of the plankton communities and the carbon flux passing through them.

In January 1997, a multidisciplinary oceanographic cruise that covered an $80 \times 80 \mathrm{~nm}$ area was carried out off the Mejillones Peninsula (see Fig. 1). In this area, zooplankton was abundant in the top $150 \mathrm{~m}$ depth where it was numerically dominated by calanoid and cyclopoid copepods, the euphausiids Euphausia mucronata (Sars) and E. eximia Hansen, and the tunicate Salpa fusiformis Cuvier, together with a diverse assemblage of gelatinous carnivores comprised of siphonophores, medusae, ctenophores and molluscs (González et al. 1998).

The large numbers of gelatinous zooplankton, whose biology is poorly known, in the HCS caused us to study this community and its relationship with the physical environment. The latter is characterized by the mixing of 3 water masses and the development of coastal upwelling along Mejillones Peninsula, as observed by satellite imaginery (Sobarzo \& Figueroa in press). Investigations in the Benguela Current System have demonstrated that populations of medusae and siphonophores are good indicators of specific water masses (Pagès \& Gili 1991a,b, Pagès 1992). We hypothesized that cnidarian populations would also be associated with specific water masses in the HCS. However, because of the wide variety of gelatinous groups in this region, a phenomenon about which little is known, we also explored the physical-biological relationships at taxon level (medusae, siphonophores, ctenophores, molluscs and salps) in this study.

Comprehensive investigations on the principal groups of gelatinous zooplankton in large-scale ecosystems are necessary to understand the functioning and ecological role of their populations. The gelatinous carnivores constitute one of the most remarkable assemblages of predators in the pelagic systems by occupying a direct link between primary consumers and top predators. Most species compete with fishes by voraciously preying upon copepods (Purcell 1992), while others feed exclusively on fish larvae (Purcell 1981a, 1984); some even prey upon other gelatinous organisms (Purcell 1991). Fish recruitment areas in upwelling regions, like the waters off the Mejillones Peninsula, might be expected to have high abundances of gelatinous predators, which might significantly influence recruitment success. The trophic impact of gelatinous carnivores is rarely assessed in large-scale ecosystems and has not been explored in upwelling regions. In this study, an attempt is made to evaluate the predatory impact on the copepod community of the siphonophore Bassia bassensis (Quoy \& Gaimard), the most abundant gelatinous carnivore in the region, in relation to the physical environment.

\section{MATERIALS AND METHODS}

Eight biological and 30 physical stations were sampled along 5 transects perpendicular to the coast, covering an area of 6400 square nautical miles (nm). The biological stations were located at 5 (coastal), 30 (transition) and 80 (oceanic) nm from the coast (Fig. 1), representing the location of the upwelling, the limit of upwelling influence, and oceanic waters, respectively. Zooplankton was collected by an obliquely towed $1 \mathrm{~m}^{2}$ Tucker trawl (200 $\mu \mathrm{m}$ mesh-size), equipped with a flowmeter, in 2 depth ranges (50 to 150 and 0 to $50 \mathrm{~m}$ ) when the ship was steaming at 2 knots. These depth ranges were chosen because the echosounder showed that most zooplankton was concentrated in the upper $50 \mathrm{~m}$ depth. On average, $50 \mathrm{~m}$ is the boundary between the upper, photic, oxygenated, low-nutrient waters where most of the phytoplankton is concentrated (González et al. 1998). It also corresponds, more

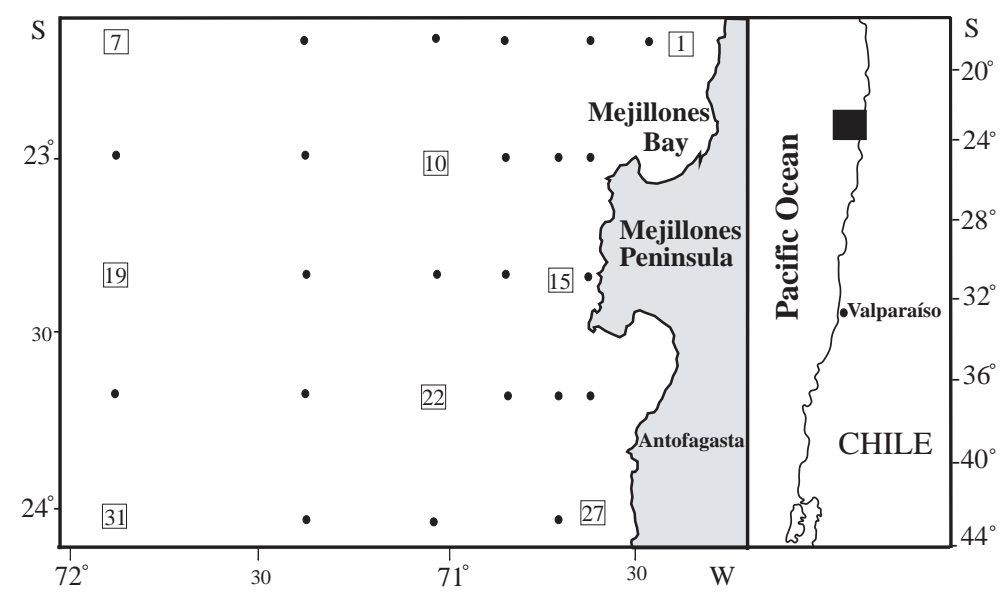

Fig. 1. Map of the area investigated showing the location of stations where physical parameters $(\bullet)$ and plankton samples (numbered) were collected 
or less, to the boundary between the Subtropical Surface Water (SSW) and the Subantarctic Waters (SAAW), since the latter occupy a narrow band centered approximately at $50 \mathrm{~m}$ depth. The boundary can be shallower near the coast. Below 50 to $70 \mathrm{~m}$, poorly oxygenated $\left(<1 \mathrm{ml} \mathrm{O}_{2} \mathrm{l}^{-1}\right)$ Equatorial Subsurface Water (ESSW) extends down to $400 \mathrm{~m}$ depth (Sobarzo \& Figueroa in press).

Siphonophores, medusae, ctenophores and molluscs were identified according to our present knowledge of the systematics of these groups. All specimens collected (whole colonies for physonect siphonophores, polygastric stages and eudoxids for calycophoran siphonophores) were counted, and the counts standardized to numbers per $1000 \mathrm{~m}^{3}$. To obtain an objective description of the distribution pattern of species and gelatinous taxa, and to characterize assemblages of samples according to their affinity based on the species composition, a cluster analysis was made after tranforming abundance data to $\log (x+1)$. The similarity coefficient of Bray-Curtis and the linkage rule of UPGMA (unweighted pair group method using arithmetic averages) (Sneath \& Sokal 1973) were used.

\section{REGIONAL HYDROGRAPHY}

The hydrographical structure of the region during the sampling period was studied by Sobarzo \& Figueroa (in press). In the area investigated, the transition zone was characterized by the mixing of SAAW flowing from the south, and both SSW and ESSW coming from the north (Fig. 2). At the open-ocean stations, SSW, characterized by warm temperatures (16 to $24^{\circ} \mathrm{C}$ ), high salinity (34.9 to 35.3 ) and high dissolved oxygen ( 4.5 to $5.5 \mathrm{ml} \mathrm{l}^{-1}$ ), extended from the surface to approximately $50 \mathrm{~m}$ depth on average (Fig. 2). However, near the coast, southeastern winds favoured an intense upwelling that affected the whole Mejillones Peninsula (Stns 1, 15 and 27). Here, at $4 \mathrm{~m}$ depth, upwelled water was identified as SAAW (Fig. 2) because of its lower salinity (34.4) and higher dissolved oxygen ( 5 to $6.8 \mathrm{ml} \mathrm{l}^{-1}$ ), although temperature was 1 to $3.5^{\circ} \mathrm{C}$ higher than for normal SAAW because of mixing with SSW.

At $50 \mathrm{~m}$ depth at the upwelling stations, the cold waters $\left(12.5\right.$ to $15^{\circ} \mathrm{C}$ ) of high salinity ( 34.6 to 34.8 ) and low dissolved oxygen ( 0 to $5 \mathrm{ml} \mathrm{l}^{-1}$ ) were separated
Fig. 2. Percentage of each water mass in the top $150 \mathrm{~m}$ depth at the plankton stations. Note large differences between Stns 1 and 15 and remainding stations. Surface layers are not plotted. The sum of percentages of the 3 water masses is higher than 100 at some stations and depths because the MATLAB program used to make the profiles solves a $3 \times 3$ matrix and the sum of percentages is not as precise when only 2 water masses are present. SSW: Subtropical Surface Water; SAAW: Subantarctic Water; ESSW: Equatorial Subsurface Water

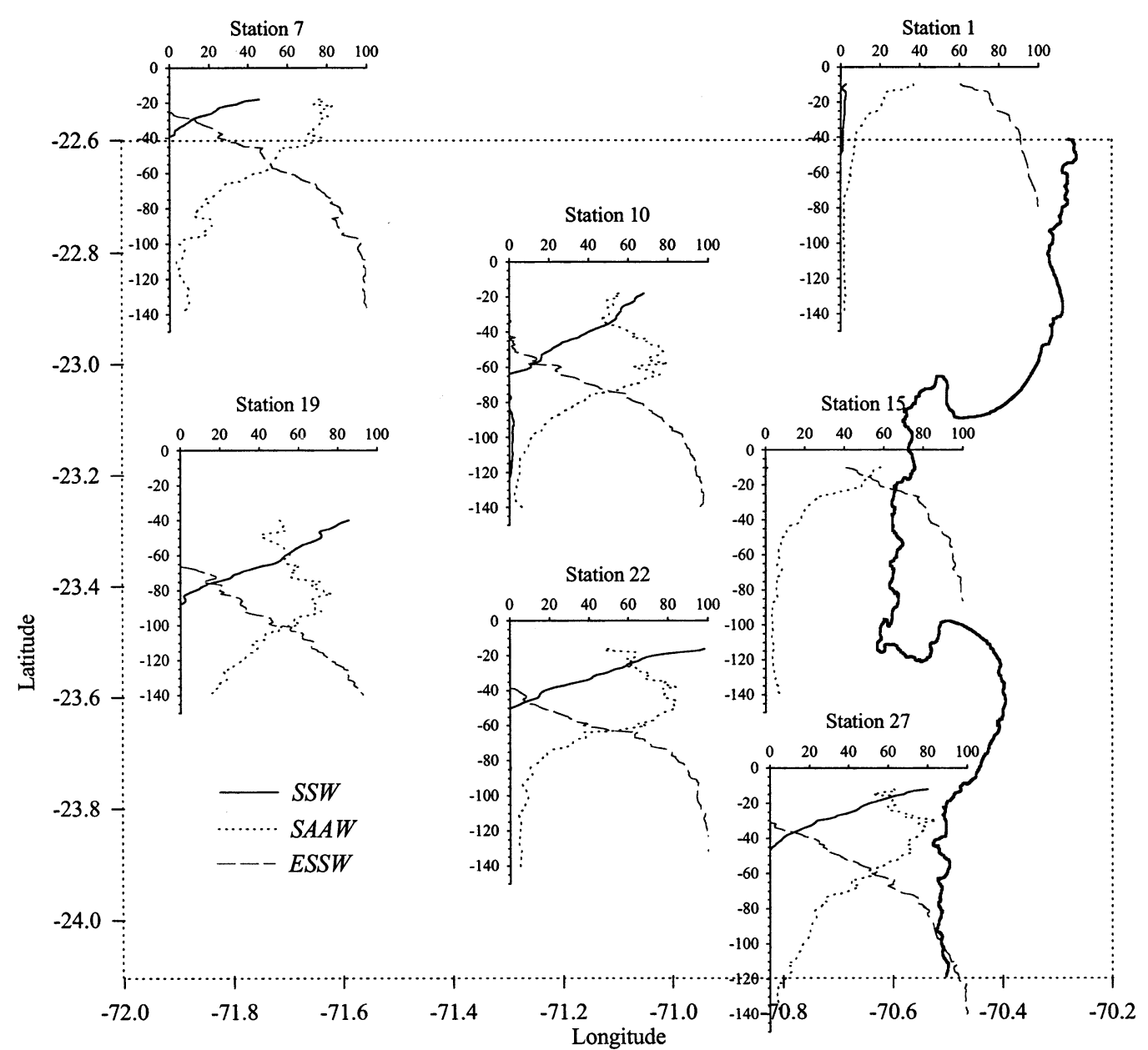




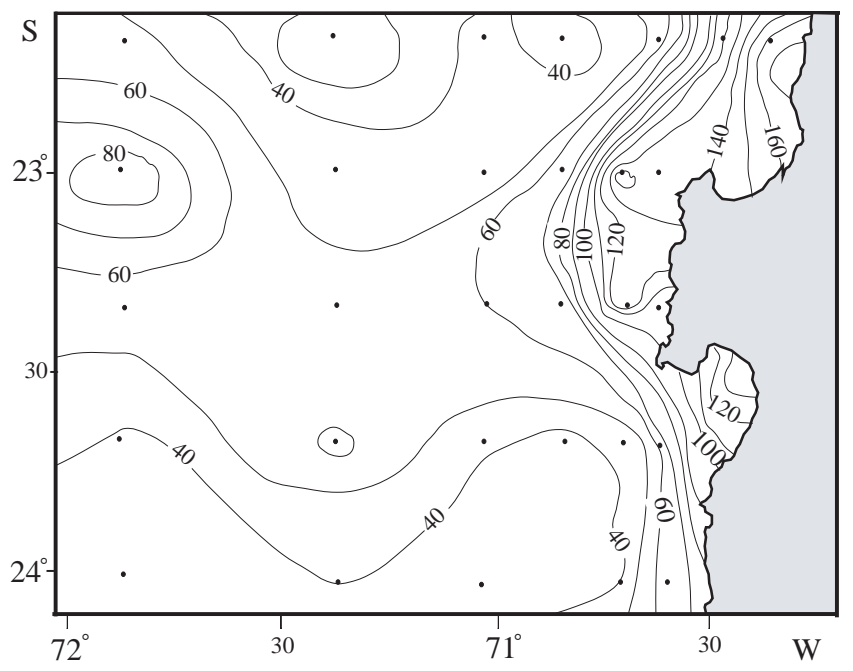

Fig. 3. Integrated (0 to $100 \mathrm{~m}$ depth range) chlorophyll $\mathrm{a}$ concentration $\left(\mathrm{mg} \mathrm{m}^{-2}\right)$ in the study area

from oceanic waters of similar characteristics by a warm $\left(15\right.$ to $\left.17^{\circ} \mathrm{C}\right)$ tongue of water with high dissolved oxygen levels which was oriented almost parallel to the coast. At this depth, the distribution of hydrographic variables showed the mixing of the 3 water masses. The upwelling of cold water affected virtually the whole coastal region. Depending on the intensity of the coastal upwelling, the ascending waters are either SAAW or ESSW. During the cruise, the characteristics of these waters reflected the presence of ESSW, with high salinity and low dissolved oxygen that enriched the photic layer with nutrients. At $100 \mathrm{~m}$ depth, the physical variables indicated the complete prevalence of ESSW.

Chlorophyll a concentrations, integrated over the top $100 \mathrm{~m}$ of the water column, showed high values (120 to $170 \mathrm{mg} \mathrm{m}^{-2}$ ) at the coastal stations associated with Mejillones and Antofagasta bays, whereas low values $\left(<50 \mathrm{mg} \mathrm{m}^{-2}\right.$ ) characterized the oceanic waters (Fig. 3).

\section{RESULTS}

\section{Mesoscale distribution}

The bulk of gelatinous carnivores (634 to 48336 specimens $1000 \mathrm{~m}^{-3}$ ) was found in the top $50 \mathrm{~m}$ at all stations compared with 80 to 12918 specimens 1000 $\mathrm{m}^{-3}$ in the 50 to $150 \mathrm{~m}$ depth range (Table 1 ). In total, 36 species (22 siphonophores, 8 medusae, 3 ctenophores and 3 molluscs) were collected. Siphonophores were the dominant group ( $>90 \%$ of abundance) at most stations. The calycophoran Bassia bassensis (polygastric stages and eudoxids up to 6 and $8 \mathrm{~mm}$ in height, respectively) was overwhelmingly the most abundant species at all stations (79.15\% of the total abundance) except at 2 coastal stations, and, in particular, the northernmost station, off Mejillones Bay, from which it was totally absent. $B$. bassensis was always densely concentrated in the 0 to $50 \mathrm{~m}$ depth range (Fig. 4), and reached highest densities at the 3 oceanic stations (up to 13622 polygastric stages and 22832 eudoxids $1000 \mathrm{~m}^{-3}$ ). In the northern half of the study area, its abundance decreased strongly towards the coast. In the southern half, abundance was high in the top $50 \mathrm{~m}$, even at the coastal station (Table 1, Fig. 4).

Muggiaea atlantica Cunningham was the second most abundant siphonophore (Table 1). Peak abundance was observed at the northernmost oceanic station, but it was not collected at the 3 coastal stations in the 50 to $150 \mathrm{~m}$ depth range. The physonect Agalma elegans (Sars) (Table 1) was the third most abundant siphonophore, with its larval stage usually considerably more numerous than the adult colonies, and greater overall abundance usually in the top $50 \mathrm{~m}$. The remainder of the siphonophore species occurred at low densities (Table 1). These species were heterogeneously distributed over the region, usually in the top $50 \mathrm{~m}$, and were virtually absent from the cold upwelled waters. It is interesting to note the discovery of an undescribed species of the prayid genus Rosacea.

Gelatinous filter-feeders, represented by the tunicate Salpa fusiformis (blastozooids up to $35 \mathrm{~mm}$ in length) constituted the second most abundant group (Table 1). They were collected at all stations except those in upwelled waters (Fig. 5), and their abundance (up to 11210 blastozooids $1000 \mathrm{~m}^{-3}$ ) was usually higher in the 50 to $150 \mathrm{~m}$ depth range in the southern part of the sampling area.

Ctenophores occurred at all stations, generally in low numbers, although they were the most conspicuous organism off Mejillones Bay, where Pleurobrachia sp. predominated (6202 specimens $1000 \mathrm{~m}^{-3}$ ) in the top $50 \mathrm{~m}$ depth (Fig. 6). This genus was also common at the northernmost oceanic station in the 50 to $150 \mathrm{~m}$ depth range $\left(477\right.$ specimens $1000 \mathrm{~m}^{-3}$ ). Specimens of Beroë sp. which is known to prey upon Pleurobrachia sp., were collected in low densities in both depth ranges at most stations.

The gelatinous molluscs were more abundant at oceanic and transition stations, where the pseudothecosome Desmopterus pacificus Essenberg, and the heteropod Firoloida desmaresti Lesueur, reached maximum densities, mostly in the top $50 \mathrm{~m}$ (Fig. 7, Table 1). The highest abundance (1008 molluscs $1000 \mathrm{~m}^{-3}$ ) was observed in a tongue of SSW near transition waters (Stn 22) where $D$. pacificus was dominant. At the southernmost oceanic station, F. desmaresti predominated throughout the top $150 \mathrm{~m}$ depth range. The larger and less abundant het- 


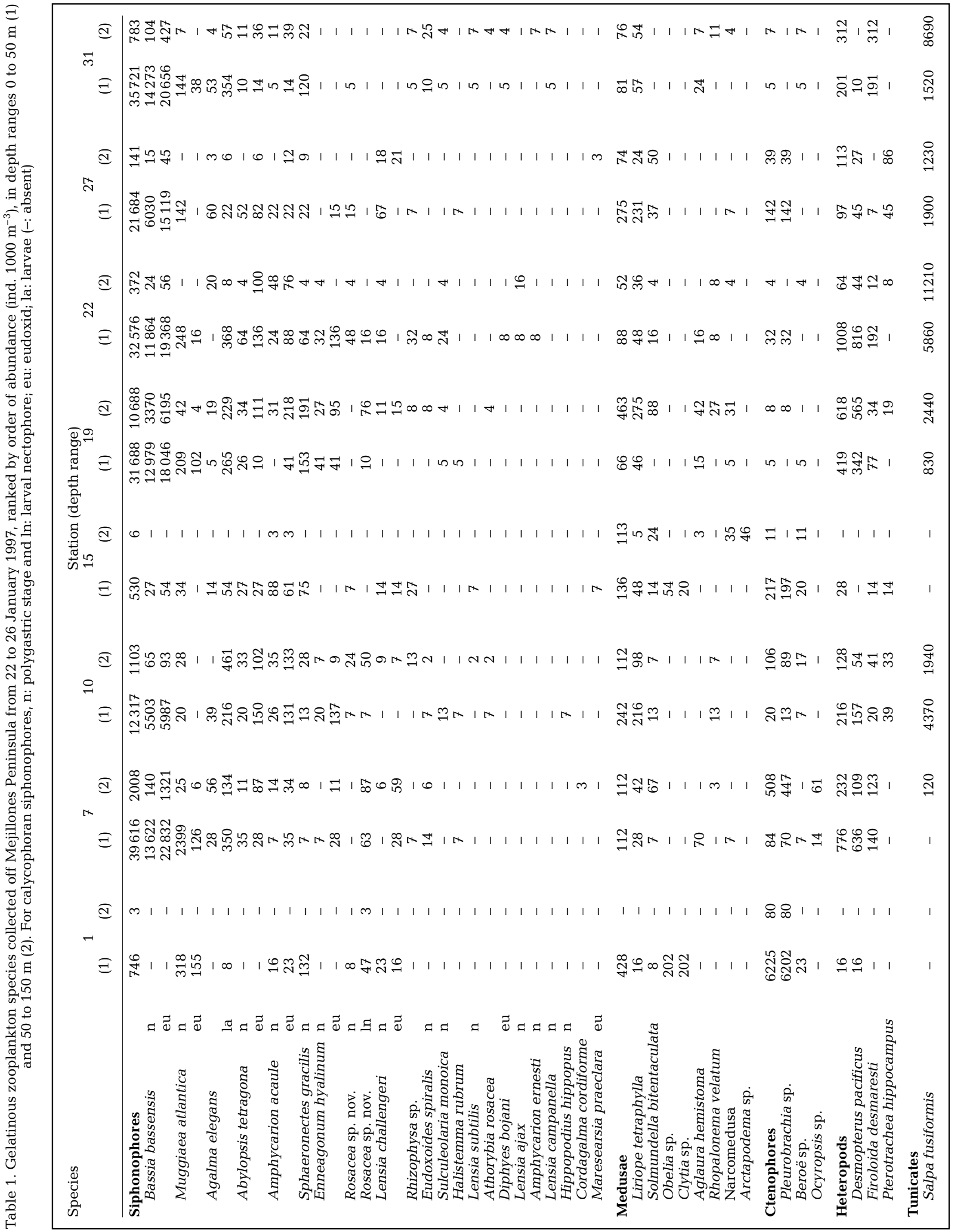




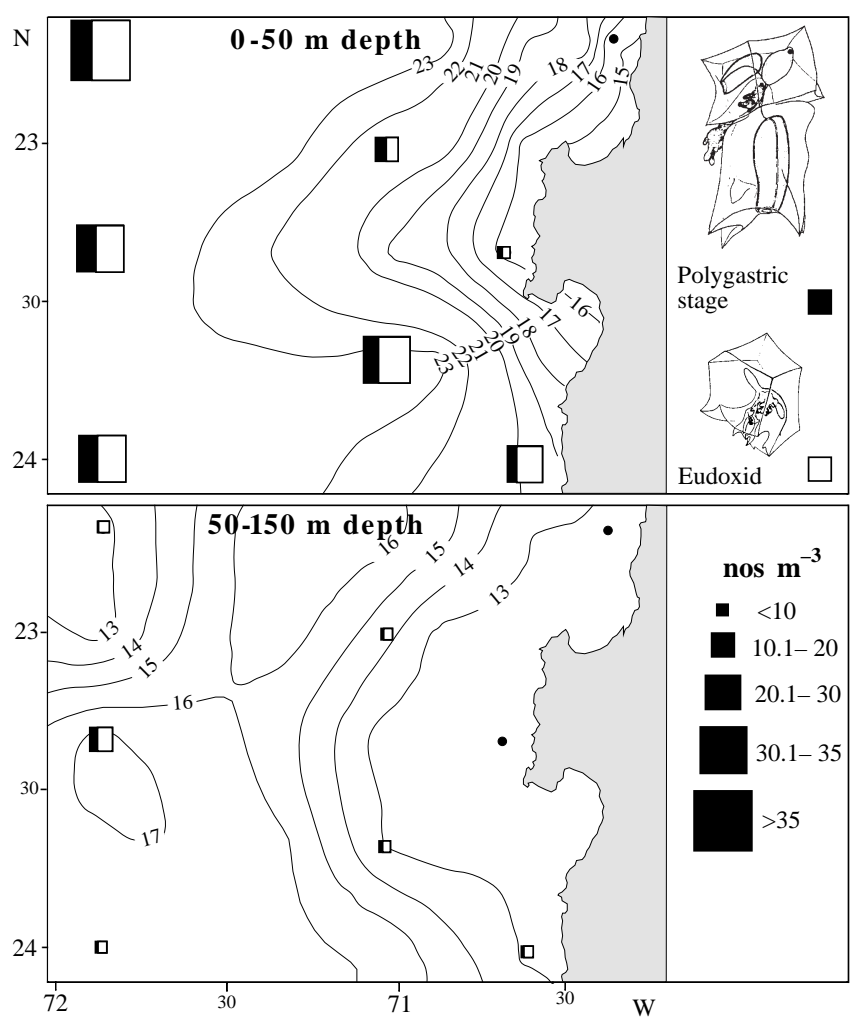

Fig. 4. Bassia bassensis. Distribution and abundance of both stages of the siphonophore in the 0 to 50 and 50 to $150 \mathrm{~m}$ depth ranges, and water temperature $\left({ }^{\circ} \mathrm{C}\right.$ : contour lines) measured at 4 and $50 \mathrm{~m}$ depth respectively

eropod Pterotrachea hippocampus Philippi mostly occurred at the transition and coastal stations, but all 3 species co-occurred at several stations.

Medusae had very low abundance and diversity, with highest numbers (428 medusae $1000 \mathrm{~m}^{-3}$ ) in the top $50 \mathrm{~m}$ off Mejillones Bay, where Obelia spp. and Clytia sp. co-occurred, and at Stn 19 (463 medusae $1000 \mathrm{~m}^{-3}$ ), where the trachymedusan Liriope tetraphylla predominated (Table 1).

\section{Cluster analysis}

The Bray-Curtis index uses both species differences and relative abundances to obtain objective information on similarity between stations. Using a similarity level $>50 \%$, the cluster analysis distinguished 3 major groups (A, B and C: Fig. 8). Table 1 shows the species composition as a function of station and depth range. Four other groups were also distinguished:

Group A consisted of the samples collected in the top $50 \mathrm{~m}$ in oceanic waters, where Bassia bassensis was overwhelmingly dominant and where it reached maximum densities.

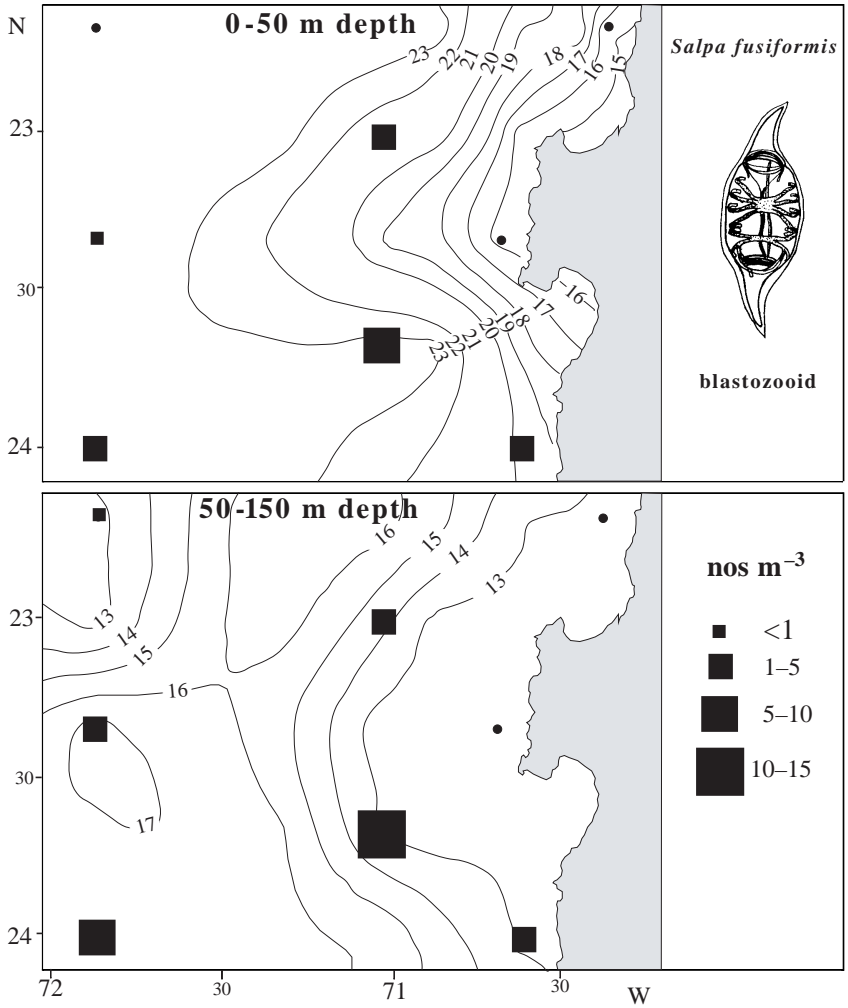

Fig. 5. Salpa fusiformis. Distribution and abundance of the pelagic tunicate in the 0 to 50 and 50 to $150 \mathrm{~m}$ depth ranges, and water temperature $\left({ }^{\circ} \mathrm{C}\right.$ : contour lines) measured at 4 and $50 \mathrm{~m}$ depth respectively. Note change in abundance scale compared to Fig. 4

Group B comprised those samples collected over both depth ranges and 3 distances from the seashore, where Bassia bassensis was very abundant and the rest of gelatinous groups also showed important densities.

Group C consisted of 2 samples collected in the 50 to $150 \mathrm{~m}$ depth range, where Salpa fusiformis was the dominant organism while many gelatinous carnivores were present, but only in low numbers.

Group D was placed just at the $50 \%$ similarity level, and included 1 sample collected in the 50 to $150 \mathrm{~m}$ depth range at a coastal station, where Salpa fusiformis was the dominant organism while the gelatinous carnivores were represented by few species in low numbers.

The 3 other groups $(E, F, G)$ were distinguished at a similarity level of $<50 \%$ (Fig. 8):

Group E consisted of 2 samples collected in the top $50 \mathrm{~m}$ at coastal stations, where the ctenophore Pleurobrachia sp. was the dominant species and Bassia bassensis was absent; Group F comprised 1 coastal sample collected in the 50 to $150 \mathrm{~m}$ depth range that had a very low abundance of gelatinous zooplankton; Group G represented 1 coastal sample collected in the 50 to $150 \mathrm{~m}$ depth range that showed the lowest abundance of gelatinous zooplankton. 


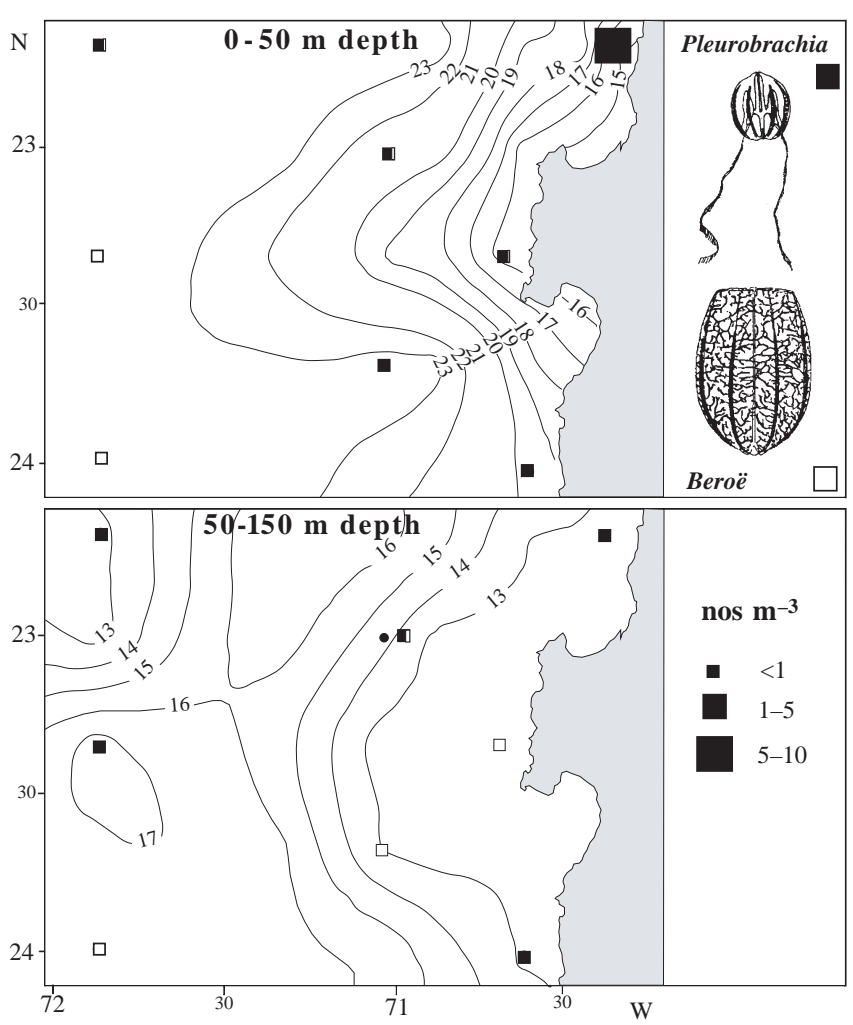

Fig. 6. Pleurobrachia sp. and Beroë sp. Distribution and abundance in the 0 to 50 and 50 to $150 \mathrm{~m}$ depth ranges, and water temperature $\left({ }^{\circ} \mathrm{C}\right.$ : contour lines) measured at 4 and $50 \mathrm{~m}$ depth respectively. Same abundance scale as Fig. 5

\section{DISCUSSION}

The mesoscale distribution of the gelatinous zooplankton off the Mejillones Peninsula was strongly influenced by the nature of the water masses present and the coastal upwelling. The community was characterized by the presence of all principal taxonomic groups and the extreme abundance of the siphonophore Bassia bassensis. Comparison of the water masses described by Sobarzo \& Figueroa (in press) with the distribution patterns of the main gelatinous taxa suggests that each water mass was mainly represented by a typical gelatinous taxa. From the 7 groups of taxa derived by the cluster analysis, 5 group associations were distinguishable in relation to the water masses identified.

\section{Siphonophores associated with SSW (Group A)}

This group was basically characterized by Bassia bassensis, the most abundant siphonophore. The highest densities of $B$. bassensis were observed at the stations where SSW prevailed (surface tempera-

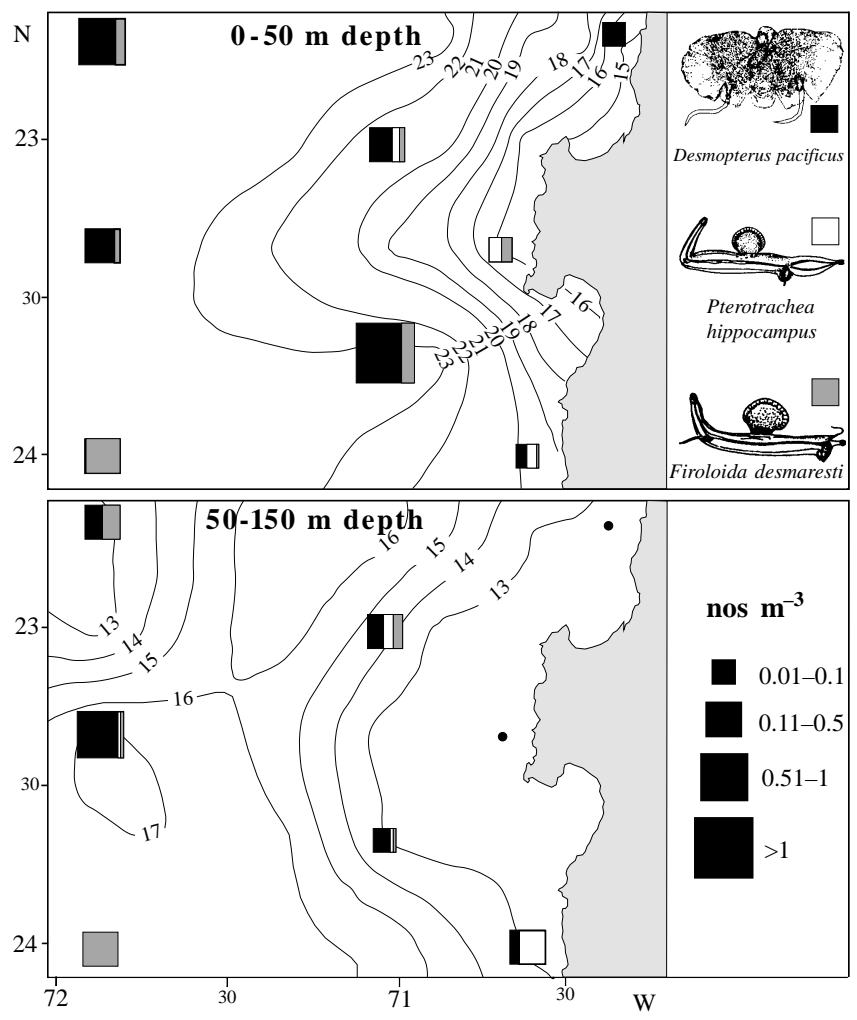

Fig. 7. Desmopterus pacificus, Pterotrachea hippocampus and Firoloida desmaresti. Distribution and abundance of 3 species of gelatinous molluscs in the 0 to 50 and 50 to $150 \mathrm{~m}$ depth ranges, and water temperature $\left({ }^{\circ} \mathrm{C}\right.$ : contour lines) measured at 4 and $50 \mathrm{~m}$ depth respectively. Note change in abundance scale compared to previous figures

ture $>19^{\circ} \mathrm{C}$ ), in contrast to its very low or zero occurrence at the coastal stations where SAAW and ESSW were predominant (surface temperature $<18^{\circ} \mathrm{C}$ ). This relatively common epipelagic calycophoran mainly occurrs in the top $50 \mathrm{~m}$ in temperate waters of the 3 main oceans and the Mediterranean Sea (Pugh 1974, Pagès \& Gili 1991a,b 1992), although abundances as high as those observed in the Humboldt Current have never been documented. Indeed these abundances are extremely high: to our knowledge, the highest reported densities for this species so far were significantly lower (0.38 polygastric and 0.48 eudoxid stages $\mathrm{m}^{-3}$ using $330 \mu \mathrm{m}$-mesh size: Lo \& Biggs 1996), and siphonophore abundances such as those found in the present study are very rare in the literature. The marked differences in abundance between the 2 depth ranges sampled indicate that the distribution of this calycophoran in the top $50 \mathrm{~m}$ may be more concentrated than at greater depths, and that a more precise vertical sampling would possibly reveal layers of dense aggregation in the 0 to $50 \mathrm{~m}$ depth interval. 


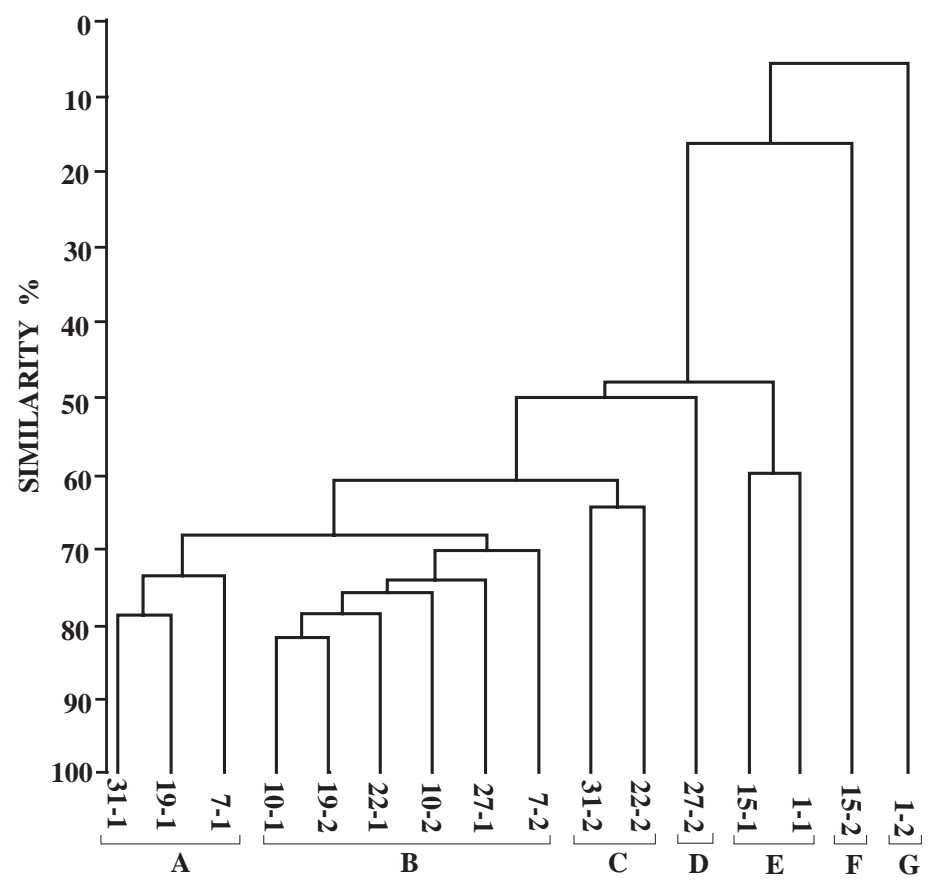

Fig. 8. Dendrogram of similarities (Bray-Curtis index) between the 16 samples collected on the basis of the distribution of the 37 gelatinous species. See Table 1 for station and depth ranges (i.e. numbers above group designations)

\section{Ctenophores associated with SAAW (Group E)}

This group, represented by Pleurobrachia sp., showed the greatest abundance at the station and depth range where SAAW was the predominant water mass with very little SSW present. The main hydrographic features were the very high surface oxygen concentrations $\left(6.8 \mathrm{mg} \mathrm{l}^{-1}\right)$. Below $25 \mathrm{~m}$, oxygen was very low $\left(<0.5 \mathrm{mg} \mathrm{l}^{-1}\right)$ due to the upwelling of ESSW, and in the 50 to 150 depth range Pleurobrachia sp. numbers were also very low (Table 1). Although this indicates that Pleurobrachia sp. mainly occurs in oxygenated waters, this relationship requires further investigation in view of several inverse relationships reported by Purcell et al. (in press).

\section{Salps associated with ESSW (Group C)}

Salpa fusiformis was usually the predominant gelatinous organism in the 50 to $150 \mathrm{~m}$ depth range at those non-upwelling stations mainly occupied by ESSW. This species has the widest world distribution of all salps, and is one of the most abundant, occurring from at least $50^{\circ} \mathrm{N}$ to $45^{\circ} \mathrm{S}$ in the Pacific Ocean (van Soest 1974). At temperate latitudes, $S$. fusiformis is known to live in colder and deeper waters than other salp species (Braconnot 1971). To relate the distribution of an individual tunicate species to hydrography has proved difficult. In the California Current, the distribution of $S$. fusiformis could not be associated with any set of physical parameters (Silver 1975). However, diatom assemblages that co-occurred with this salp were suggested as biological indicators of its habitat. Silver's work, dealing with diatom assemblages and salps, perhaps also applies to the present data despite the fact that the diatom assemblages in the 2 areas were completely different. However, it is interesting to note the inverse coupling between the distributions of $S$. fusiformis and chlorophyll a off Mejillones Peninsula. A comparison of the horizontal distribution of this salp (Fig. 5) with that of integrated chlorophyll $a$ in the top $100 \mathrm{~m}$ depth (Fig. 3) clearly shows that $S$. fusiformis was collected only at stations with medium chlorophyll a concentrations ( 40 to $70 \mathrm{mg} \mathrm{m}^{-2}$ ) and not at those stations affected by strong upwelling (120 to $160 \mathrm{mg} \mathrm{m}^{-2}$ ). Its distribution must thus be related to the concentration of particles in the water column. Laboratory experiments with the oceanic salp Pegea confoederata (Forskål) showed that its feeding mechanism was clogged at high concentrations of algae, and that this factor is probably important in excluding these organisms from areas with high levels of particulate material (Harbison et al. 1986). Similarly, Andersen (1987) showed that the specific filtration rate of $S$. fusiformis decreased exponentially with increasing particle concentration, implicitely indicating an upper limit of particle concentration for optimal filter efficiency.

\section{Assemblage of all gelatinous taxa associated with mixed waters (Group B)}

Relative high abundances of all gelatinous groups were observed at those stations and depths where SSW, SAAW and ESSW mixed (Fig. 2). Such mixing enhanced the occurrence and diversity of gelatinous organisms in the area. However, Bassia bassensis and Salpa fusiformis were the most abundant species and they characterized the community. This is the only assemblage that encompasses both depth ranges. The different trophic strategies of the main species suggest a vertical partitioning of the water column that varies between stations.

\section{Low occurrence of gelatinous taxa associated with upwelled ESSW (Groups F and G)}

The stations and depth ranges associated with ESSW upwelled from deep levels contained low numbers 
of gelatinous zooplankton. The influence of the high coastal chlorophyll levels on the distribution of the various groups has already been discussed.

The molluscs were the group least associated with a single water mass. Desmopterus pacificus was mostly found in SSW, while the distribution of heteropods was heterogeneous. The abundance and depth distribution of heteropods were similar to those already described in central Pacific waters (e.g. Seapy 1990), and could be related to the wide distribution of their main prey. These visual predators are known to feed upon other gelatinous organisms (Hamner et al. 1975) and, for example, in situ observations by divers have associated the occurrence of Pterotrachea hippocampus with dense aggregations of siphonophores (Gilmer, in: Lalli \& Gilmer 1989).

The present results are quite different from those for the southernmost waters off Valparaíso (32 to $33^{\circ} \mathrm{S}$ ) in January 1990 (Palma 1994). At that time, the ctenophore Mnemiopsis sp. was overwhelmingly the most abundant gelatinous predator (up to 83620 specimens $1000 \mathrm{~m}^{-3}$ ), Muggiaea atlantica was the most abundant siphonophore (mean 671 polygastric specimens $1000 \mathrm{~m}^{-3}$ ) and Bassia bassensis was entirely absent. Likewise, in Valparaíso Bay over an annual cycle (June 1990 to August 1991) (Palma \& Rosales 1995), again B. bassensis was not collected, while $M$. atlantica was the most abundant species. Obelia spp. and Clytia (Phialidium) sp. were the most abundant medusae and Pleurobrachia pileus was the main ctenophore. In January, $M$. atlantica and Sphaeronectes gracilis were the most abundant species and ctenophores occurred in very low densities. Thalia democratica was the most abundant salp, with mean top abundance in January, and Salpa fusiformis was not collected. These important differences and some similarities appear to indicate, under upwelling conditions, a latitudinal shift in the distribution of siphonophore species along the coast of Chile, because $M$. atlantica occurs throughout the year in Valparaíso Bay where it is positively correlated with upwelling (Palma \& Rosales 1995). Recent observations indicate that this species appears to be the most abundant siphonophore along the Chilean coast down to the Drake Strait (Palma \& Rosales 1997, Pagès \& Orejas 1999).

A comparison with the northeastern Pacific also shows meaningful differences. In Baja California, the equivalent northern latitude of the Mejillones Peninsula, Bassia bassensis appears to be more common in the Gulf (Purcell 1981b, Gasca \& Suárez 1991) than off the western coast, where it is rarely reported. For instance, when tropical waters were advected during the El Niño of 1983 (Gasca \& Suárez 1992), B. bassensis was only the 19th most abundant siphonophore. In the California Current, B. bassensis is uncommon and Muggiaea and Pleurobrachia appear to be the most abundant genera of their respective taxa. Both genera have been associated with cold upwelling waters, and do not occur in nearby warmer waters (Mackas et al. 1991, Graham et al. 1992). It is interesting to note that the gelatinous zooplankton associated with a cold filament of the California Current off Point Arena $\left(39^{\circ} \mathrm{N}\right)$ (Mackas et al. 1991) was quite similar in respect to taxa (salps, doliolids, medusae and heteropod larvae) but not to species, to the zooplankton found off the Mejillones Peninsula, where a filament was detected $10 \mathrm{~d}$ before our sampling (Sobarzo \& Figueroa in press).

The influence of coastal upwelling on the gelatinous predators of the HCS in northern Chile is markedly from that of its South Atlantic homologue, the northern Benguela Current. There, Muggiaea atlantica was the most abundant cnidarian along Namibian shelf waters (mean 138 to 1283 polygastric specimens $1000 \mathrm{~m}^{-3}$ ) (Pagès 1992) over a transition period from active upwelling to abatement (December 1981 to March 1982), and was the main species associated with upwelled waters, although its high abundance did not appear to be affected by variations in the upwelling regime. Nevertheless, it is interesting that Bassia bassensis, associated with South Atlantic Central Water, was the second species in abundance in the northern Benguela Current, although in very low numbers; i.e. the reverse of the situation in the present study.

\section{Predation}

The potential predatory impact of Bassia bassensis was estimated using data from the literature. Purcell (1981b) observed that this siphonophore fed only on copepods of 0.4 to $1.2 \mathrm{~mm}$ in length, which comprised $87.1 \%$ of a total zooplankton abundance calculated as 1695 specimens $\mathrm{m}^{-3}$. This prey-length range fits reasonably well with the size range of small copepods collected in the area under investigation (González et al. 2000). Purcell found that 60 polygastric specimens collected in situ collectively possessed 630 gastrozooids, i.e. an average of 10.5 gastrozooids per specimen. The percentage of gastrozooids with prey was $8.2 \%$. This percentage falls in the range found for other exclusive copepod-eating calycophorans of similar size (Muggiaea atlantica: 2.0 to $13.0 \%$, Sphaeronectes gracilis: $7.0 \%$, Sulculeolaria chuni: 5.3 to $17.8 \%$, Sulculeolaria monoica: 3.0 to $8.3 \%$, Sulculeolaria quadrivalvis: 3.5 to $17.4 \%$; Purcell 1981b, 1982). These 2 values (10.5 potential number and $8.2 \%$ ingested) were used to estimate the number of copepods potentially eaten by $B$. bassensis at each station and depth range in the pre- 
sent study. For the eudoxids, as each is monogastric, we have assumed that $8.2 \%$ of them had also eaten a small copepod. This percentage is conservative in comparison with the value found for the only smallsized calycophoran whose eudoxid diet has been examined $(15.2 \%$ in net-collected Lensia conoidea: Pagès et al. 1996).

The abundance of small copepods and both their potential number and percentage estimated to have been ingested by Bassia bassensis in the top $50 \mathrm{~m}$ depth at each station is shown in Table 2. Excluding the 2 coastal stations, from which $B$. bassensis was absent or where it occurred in very low numbers, the potential percentage of small copepods removed ranged between 2.9 and $69.3 \%$. These 2 extreme values occurred in the southernmost transect, at the coastal and oceanic stations respectively. The quantity of organic carbon of copepods ingested by $B$. bassensis also has been estimated (Table 2). We have assumed that there was no selectivity by $B$. bassensis and that both small calanoids and cyclopoids were captured in proportion to their respectives abundances in each sample. Values of individual carbon content for cyclopoid copepods in the length range 0.7 to $1.2 \mathrm{~mm}$ (3.5 $\mathrm{\mu g} \mathrm{C}$ ind. ${ }^{-1}$ ) and small calanoids in the 0.8 to $1.5 \mathrm{~mm}$ length range $\left(17.8 \mu \mathrm{g} \mathrm{C}\right.$ ind.$^{-1}$ ) (González et al. 2000) were used to calculate the total copepod biomass per station (Table 2). The calculation includes the largest copepods or calanoids (2 to $2.5 \mathrm{~mm}$ in length and $77.0 \mu \mathrm{g} \mathrm{C}$ ind..$^{-1}$ ), even though they are too large to be captured by $B$. bassensis, in order to encompass the whole copepod community. Excluding the 2 coastal upwelling stations, the organic carbon potentially ingested by $B$. bassensis averaged $17.3 \%$ of the copepod biomass, although the range was high (between 1.4 and $61.4 \%$ ).

The biological impact of Bassia bassensis, as for all siphonophores, is greater than would be implied from its abundance, body size or carbon content because of its large number of gastrozooids, whose tentacles occupy a volume of water in which many mesoplanktonic crustaceans are susceptible to capture. Our results indicate that Bassia bassensis was the most important secondary predator in the top $50 \mathrm{~m}$ depth and that it inflicted a significant trophic impact on the populations of small copepods off the Mejillones Peninsula during the sampling period, where small copepods constituted $80.6 \%$ of the total mesozooplankton community (González et al. 1998). However, a daily predatory estimation cannot yet be calculated until such factors as digestion time and the diel pattern of feeding of $B$. bassensis are known.

Although Bassia bassensis was the predominant predator at most stations, the occurrence of Rhizophysa sp. off Mejillones Peninsula (Table 1) is meaningful as it feeds on fish larvae: 21 specimens were collected that still had 58 gastrozooids attached. Of these $(18.9 \%)$, after dissection, 11 contained the remains of fishes. In the Gulf of California, densities of $R$. eysenhardti of up to $0.91 \pm 0.55$ ind. $\mathrm{m}^{-3}$ that predated heavily on fish larvae populations led Purcell (1981a) to suggest that their periodical occurrences could have devastating effects on recruitment of year-class fish.

Trophic models of eastern boundary upwelling systems tend to neglect the existence of gelatinous predators (e.g. Cole \& McGlade 1998), and therefore the paradox of direct predatory impact upon a higher trophic level. In the northern Benguela Current, the increasing evidence of high biomasses of salps and jellyfish (4th in a ranking of 24 groups) led to the inclusion of both taxa in the latest model on trophic flows of that ecosystem (Shannon \& Jarre-Teichmann 1999). However, the numerous assumptions and the lack of correct data about their trophic impact resulted in the erroneus conclusion that gelatinous zooplankton is relatively unimportant in the trophic functioning of the northern Benguela Current (Shannon \& Jarre-Teichmann 1999). The present data show that, for modelling large-scale and upwelling ecosystems, there is an urgent need for knowledge about the production and

Table 2. Abundance of small copepods (small calanoids and cyclopoids) in the 0 to $50 \mathrm{~m}$ depth range at the 8 stations sampled and percentage potentially ingested by Bassia bassensis; percentage of total copepod carbon biomass potentially ingested by this siphonophore is also shown

\begin{tabular}{|c|c|c|c|c|c|c|c|c|}
\hline & \multicolumn{8}{|c|}{ Station } \\
\hline & 1 & 7 & 10 & 15 & 19 & 22 & 27 & 31 \\
\hline Small calanoids $\mathrm{m}^{-3}$ & 80.8 & 136.4 & 35.4 & 218.4 & 62.0 & 27.0 & 93.0 & 16.0 \\
\hline Cyclopoids $\mathrm{m}^{-3}$ & 3.4 & 111.9 & 17.4 & 25.6 & 206.0 & 10.8 & 126.2 & 4.1 \\
\hline No copepods $\mathrm{m}^{-3}$ ingested & 0 & 13.6 & 5.2 & 0.02 & 12.6 & 11.8 & 6.4 & 13.9 \\
\hline No small calanoids + cyclopoids $\mathrm{m}^{-3}$ ingested & 0 & $7.5+6.1$ & $3.5+1.7$ & 0 & $2.9+9.7$ & $8.4+3.4$ & $2.7+3.7$ & $11.8+2.8$ \\
\hline Small copepods ingested (\%) & 0 & 5.4 & 9.8 & 0 & 4.7 & 31.0 & 2.9 & 69.3 \\
\hline Small copepods biomass $\left(\mu \mathrm{g} \mathrm{C} \mathrm{m} \mathrm{C}^{-3}\right)$ & 1551.9 & 2819.7 & 691.5 & 3977.1 & 1824.6 & 518.4 & 2097.8 & 300.8 \\
\hline Total copepod biomass $\left(\mu \mathrm{g} \mathrm{C} \mathrm{m}^{-3}\right)$ & 2709.3 & 4329.7 & 835.5 & 5715.8 & 3595.6 & 762.5 & 4217.5 & 341.7 \\
\hline Total copepod biomass ingested (\%) & 0 & 3.57 & 8.16 & 0 & 1.76 & 22.1 & 1.44 & 61.4 \\
\hline
\end{tabular}


consumption rates of gelatinous zooplankton on a temporal basis in order to assess correctly the flux of energy and matter that passes through this complicated assemblage of organisms.

Acknowledgements. This research was funded by a CSICCONICYT project and the Fondecyt Sectorial project 5960002-1996, with additional travel support from the Fondap $\mathrm{O}$ and BM program. We thank Phil Pugh and 2 anonymous referees for comments on the manuscript.

\section{LITERATURE CITED}

Alheit J, Bernal P (1993) Effects of physical and biological changes on the biomass yield of the Humboldt Current Ecosystem. In: Sherman K, Alexander L, Gold BD (eds) Large marine ecosystems: stress, mitigation and sustainability. American Association for the Advancement of Science, Washington, p 53-68

Andersen V (1987) Filtration and ingestion rates of Salpa fusiformis Cuvier (Tunicata: Thaliacea): effects of size, individual weight and algal concentration. J Exp Mar Biol Ecol 87:13-29

Braconnot JC (1971) Contribution à l'étude biologique et écologique des Tuniciers pelagiques Salpides et Doliolides. II. Hydrologie et écologie des Salpides. Vie Milieu Ser B 22: 257-286

Cole J, MacGlade V (1998) Clupeoid population variability, the environment and satellite imagery in coastal upwelling systems. Rev Fish Biol Fish 8:445-471

Gasca R, Suárez E (1991) Nota sobre los sifonóforos (Cnidaria: Siphonophora) del golfo de California (agosto-septiembre, 1977). Cienc Pesq Mexico 8:119-125

Gasca R, Suárez E (1992) Sifonóforos (Cnidaria: Hydrozoa) de la zona sudoccidental de la península de Baja California, en invierno y verano durante 'El Niño' 1983. Rev Inv Cient $3: 37-46$

González HE, Daneri G, Figueroa D, Iriarte JL, Lefevre N, Pizarro G, Quiñones R, Sobarzo M, Troncoso A (1998) Producción primaria y su destino en la trama trófica pelágica y océano profundo e intercambio océano-atmósfera de $\mathrm{CO}_{2}$ en la zona norte de la corriente de Humboldt $\left(23^{\circ} \mathrm{S}\right)$ : posibles efectos del evento El Niño, 1997-98 en Chile. Rev Chil Hist Nat 71:429-458

González HE, Sobarzo M, Figueroa D, Nöthig EM (2000) Composition, biomass and potential grazing impact of the crustacean and pelagic tunicates in the northern Humboldt Current area off Chile: differences between El Niño and non-El Niño years. Mar Ecol Prog Ser 195: 201-220

Graham WM, Field JG, Potts DC (1992) Persistent 'upwelling shadows' and their influence on zooplankton distributions. Mar Biol 114:561-570

Hamner WM, Madin LP, Alldredge AL, Gilmer RW, Hamner PP (1975) Underwater observations on gelatinous zooplankton: sampling problems, feeding biology and behavior. Limnol Oceanogr 20:907-917

Harbison GR, McAlister VL, Gilmer RW (1986) The response of the salp, Pegea confoederata, to high levels of particulate material: starvation in the midst of plenty. Limnol Oceanogr 31:371-382

Lalli CM, Gilmer RW (1989) Pelagic snails. The biology of holoplanktonic gastropod mollusks. Stanford University Press, Stanford, CA
Lo WT, Biggs DC (1996) Temporal variability in the night-time distribution of epipelagic siphonophores in the North Atlantic Ocean at Bermuda. J Plankton Res 18:923-939

Mackas DL, Washburn L, Smith SL (1991) Zooplankton community pattern associated with a California Current cold filament. J Geophys Res 96C8:14781-14797

Pagès F (1992) Mesoscale coupling between planktonic cnidarian distribution and water masses during a temporal transition between active upwelling and abatement in the northern Benguela system. S Afr J Mar Sci 12:41-52

Pagès F, Gili JM (1991a) Vertical distribution of epipelagic siphonophores at the confluence between Benguela waters and the Angola Current over 48 hours. Hydrobiologia 216/217:355-362

Pagès F, Gili JM (1991b) Effects of large-scale advective processes on gelatinous zooplankton populations in the northern Benguela ecosystem. Mar Ecol Prog Ser 75: 205-215

Pagès F, Gili JM (1992) Siphonophores (Cnidaria, Hydrozoa) of the Benguela Current (southeastern Atlantic). Sci Mar 56(Suppl 1):65-112

Pagès F, Orejas C (1999) Medusae, siphonophores and ctenophores of the Magellan region. Sci Mar 63(Suppl 1):43-50

Pagès F, González HE, González SR (1996) Diet of gelatinous zooplankton in Hardangerfjord (Norway) and potential predatory impact by Aglantha digitale (Trachymedusae). Mar Ecol Prog Ser 139:69-77

Palma S (1994) Distribución del macroplancton gelatinoso en un área de desove de peces frente a la costa central de Chile $\left(32^{\circ}-33^{\circ} \mathrm{S}\right)$. Rev Biol Mar 29:23-45

Palma S, Rosales S (1995) Composición, distribución y abundancia estacional del macroplancton de la bahía de Valparaíso. Inv Mar Valparaíso 23:49-66

Palma S, Rosales S (1997) Sifonóforos epipelágicos de los canales australes chilenos $\left(41^{\circ} 30^{\prime}-46^{\circ} 40^{\prime} \mathrm{S}\right)$. Cienc Tecnol Mar 20:125-145

Pugh PR (1974) The vertical distribution of the siphonophores collected during the SOND cruise, 1965. J Mar Biol Assoc UK 54:25-90

Purcell JE (1981a) Feeding ecology of Rhizophysa eysenhardti, a siphonophore predator of fish larvae. Limnol Oceanogr 26:424-432

Purcell JE (1981b) Dietary composition and diel feeding patterns of epipelagic siphonophores. Mar Biol 65:83-90

Purcell JE (1982) Feeding and growth of the siphonophore Muggiaea atlantica (Cunningham, 1893). J Exp Mar Biol Ecol 62:39-54

Purcell JE (1984) Predation on fish larvae by Physalia physalis, the Portuguese man of war. Mar Ecol Prog Ser 19:189-191

Purcell JE (1991) A review of cnidarians and ctenophores feeding on competitors in the plankton. Hydrobiologia 216/217:335-342

Purcell JE (1992) Effects of predation by the scyphomedusan Chrysaora quinquecirrha on zooplankton populations in Chesapeake Bay, USA. Mar Ecol Prog Ser 87:65-76

Purcell JE, Breitburg D, Decker MB, Graham WM, Youngbluth MJ, Raskoff KA (in press) Pelagic cnidarian and ctenophores in low dissolved oxygen environments: a review. In: Rabalais NN, Turner RE (eds) Effects of hypoxia on living resources

Seapy RR (1990) Patterns of vertical distribution in epipelagic heteropod molluscs off Hawaii. Mar Ecol Prog Ser 60: 235-246

Sernapesca (1998) Anuario estadístico de pesca 1997. Servicio Nacional de Pesca. Ministerio de Economía, Fomento y Reconstrucción de Chile, Valparaíso 
Sernapesca (1999) Anuario estadístico de pesca 1998. Servicio Nacional de Pesca. Ministerio de Economía, Fomento y Reconstrucción de Chile, Valparaíso

Shannon LJ, Jarre-Teichmann A (1999) A model of trophic flows in the northern Benguela upwelling system during the 1980s. S Afr J Mar Sci 21:349-366

Silver MW (1975) The habitat of Salpa fusiformis in the California Current as defined by indicator assemblages. Limnol Oceanogr 20:230-237

Editorial responsibility: Jennifer Purcell (Contributing Editor), Cambridge, Maryland, USA
Sneath PHA, Sokal RR (1973) Numerical taxonomy-the principles and practice of numerical classification. WH Freeman \& Co, San Francisco

Sobarzo M, Figueroa D (in press) The physical structure of a cold filament in an upwelling zone (Península de Mejillones, Chile $\left.23^{\circ} \mathrm{S}\right)$. J Geophys Res

van Soest RWM (1974) A revision of the genera Salpa Forskal, 1775, Pegea Savigny, 1816 and Ritteriella Metcalf, 1919 (Tunicata, Thaliacea). Beaufortia 22:153-191

Submitted: February 28, 2000; Accepted: June 22, 2000 Proofs received from author(s): January 8, 2001 